\title{
A COMPARATIVE STUDY OF THE EFFICACY OF TOPICAL HYDROGEL DRESSINGS AND CONVENTIONAL DRESSINGS IN CHRONIC WOUNDS
}

\author{
Sushila P. Garag1, Mohan Kamdal'2, Abdul Aziz Riyaz³, Sajid Mudhol ${ }^{4}$ \\ ${ }_{1}^{1}$ Associate Professor, Department of General Surgery, Al-Ameen Medical College and Research Centre, Vijayapura, Karnataka, India. \\ ${ }^{2}$ Assistant Professor, Department of General Surgery, Al-Ameen Medical College and Research Centre, Vijayapura, Karnataka, India. \\ ${ }^{3}$ Resident, Department of General Surgery, Al-Ameen Medical College and Research Centre, Vijayapura, Karnataka, India. \\ 4 Professor and HOD, Department of General Surgery, Al-Ameen Medical College and Research Centre, Vijayapura, Karnataka, India.
} ABSTRACT

\section{BACKGROUND}

In this millennium where mankind has succeeded in deciphering the human genetic code, the issue of chronic wound management still remains an enigmatic challenge. Chronic wounds, especially non-healing types, are one of the most common surgical conditions a surgeon comes across. From time immemorial, doctors have been trying many methods to treat these types of wounds.

\section{MATERIALS AND METHODS}

This was a quasi-experimental study. Patients admitted with chronic wounds were admitted in General Surgery Department of Al Ameen Medical College, Bijapur.

\section{RESULTS}

The reduction of slough is as early as 3rd week in the test group than the control group. The number of patients with $75-100 \%$ wound filled with granulation tissue in as early as 3rd week in test group than the control group, where it took more than 4 weeks. The number of patients who underwent secondary suturing, skin graft and flap are significantly higher and also as early as 3rd week in test group than the control group.

\section{CONCLUSION}

Hydrogel is an effective topical applicant in reduction of slough, promoting granulation tissue formation and re-epithelialisation and reduces hospital stay of these patients. This helps in faster wound bed preparation for healing, suturing, skin graft and flap in comparison with conventional treatment with local antiseptics.

\section{KEY WORDS}

Hydrogel; Chronic Wounds; Rate of Granulation Tissue; Hospital Stay.

HOW TO CITE THIS ARTICLE: Garag SP, Kamdal M, Riyaz AA, et al. A comparative study of the efficacy of topical hydrogel dressings and conventional dressings in chronic wounds. J. Evolution Med. Dent. Sci. 2018;7(37):4067-4071, D0I: $10.14260 /$ jemds/2018/909

\section{BACKGROUND}

The treatment of chronic wounds is of high clinical and socioeconomic importance, since chronic wounds are frequent ${ }^{[1]}$ (Upto 2 million Germans suffering from chronic wound show long courses of disease, pose a substantial burden of disease and raise high costs of illness).[2-3] A wound care revolution is currently in the making. Many techniques have been tried over the centuries to heal chronic leg ulcers. Although, wound dressings have been used for at least two millennia, there exists no ideal dressing. Surgical dressing of both open and closed wounds is based mainly on tradition, training and the surgeon's own philosophy. During the last two decades, a wide variety of innovative dressings have been introduced.

Recent studies have shown that application of a topical hydrogel in a controlled manner to the wound site has got an important role in assisting wound healing.

'Financial or Other Competing Interest': None.

Submission 25-07-2018, Peer Review 26-08-2018,

Acceptance 31-08-2018, Published 10-09-2018.

Corresponding Author:

Dr. Sushila P. Garag,

Associate Professor,

Department of General Surgery,

Al-Ameen Medical College and Research Centre,

Vijayapura, Karnataka, India.

E-mail: sushilapg@gmail.com

DOI: $10.14260 /$ jemds $/ 2018 / 909$
The present study was conducted to assess the efficacy of topical hydrogel wound dressings as compared to conventional wound dressings in improving the healing process in chronic wounds and to prove that topical hydrogel dressings can be used as a much better treatment option in the management of chronic wounds. However, clinical trials, reviews and meta-analysis ${ }^{[4-9]}$ of the effectiveness of dressings in the treatment of chronic wounds show heterogeneous results and thus present varying conclusions and recommendations.

\section{MATERIALS AND METHODS}

This was a quasi-experimental study. All patients with chronic wounds, of varying aetiology, admitted in Al Ameen Medical College Hospital, Bijapur, from 2012 to 2014 satisfying all the inclusion criteria mentioned below after the clearance from the Ethical Committee was obtained.

Inclusion criteria are: - 1. Patients with age between $20-60$ years; 2. All types of chronic wounds irrespective of aetiology; 3. Wound size $<10 \%$ TBSA; 4 . Patients giving consent for topical hydrogel wound dressings.

Exclusion criteria are: - 1 . Wounds with necrotic tissue; 2. Untreated underlying osteomyelitis; 3 . Fistulas to organs or body cavities; 4 . Exposed arteries or veins; 5. Malignancy within wounds; 6 . Dry gangrene. 
A total of 100 patients, who fulfilled the above inclusion criteria from Al-Ameen Medical College and Hospital, Bijapur, will be included in the study. This sample size of 50 in each group was taken for convenience.

The whole sample population was to be divided into two equal and comparable groups of 50 patients, based on the willingness for undergoing topical hydrogel dressing. Those who were not willing were subjected to conventional wound dressings and formed the control group. These groups were further split into two equal groups of 25 patients each, based on those who have diabetes and those without diabetes. Thus, the whole study population was divided into four groups. Selection of patients was done by purposive sampling method. Care was taken so that all the groups had a comparable distribution of patients with regards to age as well as aetiology of the ulcer.

The selected patients underwent screening for a period of one to two weeks, to stabilise the wound and institute appropriate medical and surgical line of treatment like diabetic control, control of infection by initiating appropriate antibiotic based on culture sensitivity report, surgical debridement, correction of anaemia and correction of other medical illness. All patients underwent detailed clinical examination and relevant investigations. After the initial screening, the eligible patients who required bedside debridement were divided into test group and control group-

1. Test Group: Received hydrogel with colloidal silver along with bedside surgical debridement whenever required for wounds/ ulcers, which had slough in the floor and still granulation tissue appeared.

2. Control Group: Received bedside surgical debridement with Povidone-Iodine dressings.

The test medication hydrogel with colloidal silver was applied to the test group once daily using an artery forceps. Enough medication was applied over the entire surface of the slough and only superficial slough was removed using bedside surgical debridement whenever required. Treatment of control group was done with bedside surgical debridement whenever required and conventional dressing with topical Povidone-Iodine once daily.

Wounds were treated once daily until complete debridement or upto seven weeks. The amount of non-viable tissue, degree of wound granulation and overall wound response was evaluated weekly using a visual score.

\section{The Visual Scores are as follows (1)}

a. The score for the percentage of wound covered by slough and non-viable (necrotic) tissue are $1 .=76-100 \%$ wound covered with non-viable tissue; $2 .=51-75 \%$ wound covered with non-viable tissue; $3 .=26-50 \%$ wound covered with non-viable tissue; 4. = 11-25\% wound covered with non-viable tissue; $5 .=0-10 \%$ wound covered with non-viable tissue; $6 .=$ No necrotic tissue. b. The score for the percentage of wound covered by granulation tissue are-

1. No granulation present, $2 .<25 \%$ of wound covered by granulation tissue, 3. $25-74 \%$ of wound covered by granulation tissue, $4.75-100 \%$ of wound covered by granulation tissue. The reduction of wound size and area was measured in $\mathrm{cm}^{2}$. The final parameters and wound characteristics of the two groups were analysed and compared.

\section{Statistical Analysis}

The qualitative data was expressed by Chi-square test. Fisher's test was used. For statistical analysis, SPSS software version 25.0 was used.

\section{RESULTS}

Most of the patients fell in the age group between 40 years and 60 years. The mean \pm SD for test group is (53.87 \pm 6.52 ) and control is (53.76 \pm 6.69$)$, so age distribution is statistically similar between the two groups with $\mathrm{p}>0.05$. The male and female ratio of the test group is $62 \%: 38 \%$ and the control group is $68 \%: 32 \%$. Hence, sex distribution is statistically similar between the two groups with $\mathrm{p}>0.05$.

The mean size of the ulcer was 9.68 to $10.74 \mathrm{~cm}$. The mean \pm SD of the size of ulcer in test group $(9.68 \pm 5.73)$ and in control group $(10.74 \pm 6.34)$ is statistically similar between the two groups with $\mathrm{p}>0.05$. All the patients included in the study were suffering from chronic ulcers of varied aetiology. The underlying aetiologies of the ulcers were largely comparable in both groups. The main aetiology in both groups was diabetes mellitus followed by postinfective raw areas.

The number of patients with no necrotic tissue are significantly higher in the test group at 3rd week follow-up $(\mathrm{p}<0.001)$, at 4 th week $(\mathrm{p}<0.001)$, at 5 th week $(\mathrm{p}<0.001)$, at 6 th week $(p<0.001)$ and at the 7 th week $(p<0.01)$ when compared to control group as per the Chi-square/ Fisher Exact test (shown in Table No. 1).

The number of patients with 75 - 100\% wound filled with granulation tissue were significantly higher in test group at 3rd week follow-up ( $p<0.001)$, at 4th week ( $p<$ $0.001)$, at 5 th week $(p<0.001)$, at 6 th week $(p<0.001)$ and at the 7 th week $(\mathrm{p}<0.05)$ when compared to control group as per the Chi-square/ Fisher's Exact test (Shown in Table No. 2).

The number of patients with no wound surface (Nil) are significantly higher in Test group at 3rd week follow-up $(\mathrm{p}<0.05)$, at 4 th week $(\mathrm{p}<0.05)$, at 5 th week $(\mathrm{p}<0.05)$, at 6 th week $(p<0.001)$ and at the 7 th week $(p<0.001)$ when compared to control group as per the Chi-square/ Fisher's Exact test (Shown in Table No. 3). The mean hospital stay in test group was $42.9 \pm 3.58$ (SD) days and that in control group was $47.61 \pm 1.72$ (SD) days. The results of the hydrogel dressing is shown in the figures $1,2,3,4,5$ with comparison with conventional dressings. 


\begin{tabular}{|c|c|c|c|c|c|c|c|c|c|c|c|c|}
\hline \multirow{2}{*}{ Study Period } & \multicolumn{6}{|c|}{$\begin{array}{l}\text { Test Group }(n=50) \text { Visual Score of } \\
\text { Slough Covering the Ulcer }\end{array}$} & \multicolumn{6}{|c|}{$\begin{array}{c}\text { Control Group (n=50) Visual } \\
\text { Score of Slough Covering the Ulcer }\end{array}$} \\
\hline & 1 & 2 & 3 & 4 & 5 & 6 & 1 & 2 & 3 & 4 & 5 & 6 \\
\hline & & $\begin{array}{c}14 \\
(28 \%)\end{array}$ & $\begin{array}{c}8 \\
(16 \%) \\
\end{array}$ & $\begin{array}{c}1 \\
(2 \%)\end{array}$ & - & - & $\begin{array}{c}28 \\
(56 \%)\end{array}$ & $\begin{array}{c}13 \\
(26 \%) \\
\end{array}$ & $\begin{array}{c}9 \\
(18 \%)\end{array}$ & & & \\
\hline $1^{\text {st }}$ Week & $\begin{array}{c}12 \\
(24 \%)\end{array}$ & $\begin{array}{c}13 \\
(26 \%)\end{array}$ & $\begin{array}{c}8 \\
(16 \%)\end{array}$ & $\begin{array}{c}9 \\
(18 \%)\end{array}$ & $\begin{array}{c}7 \\
(14 \%)\end{array}$ & $\begin{array}{c}1 \\
(2 \%) \\
\end{array}$ & $\begin{array}{c}23 \\
(46 \%) \\
\end{array}$ & $\begin{array}{c}12 \\
(24 \%)\end{array}$ & $\begin{array}{c}6 \\
(12 \%) \\
\end{array}$ & $\begin{array}{c}5 \\
(10 \%) \\
\end{array}$ & $\begin{array}{c}4 \\
(8 \%) \\
\end{array}$ & \\
\hline $2^{\text {nd }}$ Week & $\begin{array}{c}1 \\
(2 \%)\end{array}$ & $\begin{array}{c}11 \\
(22 \%) \\
\end{array}$ & $\begin{array}{c}8 \\
(16 \%) \\
\end{array}$ & $\begin{array}{c}3 \\
(6 \%) \\
\end{array}$ & $\begin{array}{c}13 \\
(26 \%) \\
\end{array}$ & $\begin{array}{c}14 \\
(28 \%) \\
\end{array}$ & $\begin{array}{c}6 \\
(12 \%) \\
\end{array}$ & $\begin{array}{c}20 \\
(40 \%) \\
\end{array}$ & $\begin{array}{c}7 \\
(14 \%) \\
\end{array}$ & $\begin{array}{c}5 \\
(10 \%) \\
\end{array}$ & $\begin{array}{c}3 \\
(6 \%) \\
\end{array}$ & $\begin{array}{c}9 \\
(18 \%) \\
\end{array}$ \\
\hline $3^{\text {rd } W e e k}$ & - & $\begin{array}{c}2 \\
(4 \%)\end{array}$ & $\begin{array}{c}5 \\
(10 \%)\end{array}$ & $\begin{array}{c}15 \\
(30 \%)\end{array}$ & 0 & $\begin{array}{c}28 \\
(56 \%)\end{array}$ & $\begin{array}{c}2 \\
(4 \%)\end{array}$ & $\begin{array}{c}14 \\
(28 \%)\end{array}$ & $\begin{array}{c}10 \\
(20 \%)\end{array}$ & $\begin{array}{c}5 \\
(10 \%)\end{array}$ & $\begin{array}{c}7 \\
(14 \%)\end{array}$ & $\begin{array}{c}12 \\
(24 \%)\end{array}$ \\
\hline $4^{\text {th }}$ Week & & & $\begin{array}{c}2 \\
(4 \%)\end{array}$ & $\begin{array}{c}6 \\
(12 \%)\end{array}$ & $\begin{array}{c}7 \\
(14 \%)\end{array}$ & $\begin{array}{c}35 \\
(70 \%)\end{array}$ & & $\begin{array}{c}1 \\
(2 \%)\end{array}$ & $\begin{array}{c}15 \\
(30 \%)\end{array}$ & $\begin{array}{c}10 \\
(20 \%)\end{array}$ & $\begin{array}{c}6 \\
(12 \%)\end{array}$ & $\begin{array}{c}17 \\
(34 \%)\end{array}$ \\
\hline $5^{\text {th }}$ Week & & & & $\begin{array}{c}3 \\
(6 \%)\end{array}$ & $\begin{array}{c}5 \\
(10 \%)\end{array}$ & $\begin{array}{c}42 \\
(84 \%)\end{array}$ & & & $\begin{array}{c}5 \\
(10 \%)\end{array}$ & $\begin{array}{c}13 \\
(26 \%)\end{array}$ & $\begin{array}{c}11 \\
(22 \%)\end{array}$ & $\begin{array}{c}21 \\
(42 \%)\end{array}$ \\
\hline $6^{\text {th }}$ Week & & & & & $\begin{array}{c}2 \\
(4 \%)\end{array}$ & $\begin{array}{c}48 \\
(96 \%) \\
\end{array}$ & & & & $\begin{array}{c}8 \\
(16 \%)\end{array}$ & $\begin{array}{c}14 \\
(28 \%) \\
\end{array}$ & $\begin{array}{c}28 \\
(56 \%) \\
\end{array}$ \\
\hline $7^{\text {th }}$ Week & & & & & & $\begin{array}{c}50 \\
(100 \%)\end{array}$ & & & & & $\begin{array}{c}10 \\
(20 \%) \\
\end{array}$ & $\begin{array}{c}40 \\
(80 \%) \\
\end{array}$ \\
\hline \multicolumn{13}{|c|}{ Table 1. Presence of Necrotic Tissue or Slough } \\
\hline Inference & \multicolumn{12}{|c|}{$\begin{array}{l}\text { Number of patients with No Necrotic tissue are significantly higher in Test group } \\
\text { at 3rd week follow-up }(\mathrm{p}<0.001) \text {, at } 4 \text { th week }(\mathrm{p}<0.001) \text {, at } 5 \text { th week }(\mathrm{p}<0.001) \text {, at } 6 \text { th week } \\
(\mathrm{p}<0.001) \text { and at the } 7 \text { th week }(\mathrm{p}<0.01) \text { when compared to control group as per the Chi-square } / \text { Fisher's Exact test }\end{array}$} \\
\hline
\end{tabular}

\begin{tabular}{|c|c|c|c|c|c|c|c|c|}
\hline \multirow{2}{*}{$\begin{array}{c}\text { Study } \\
\text { Period }\end{array}$} & \multicolumn{4}{|c|}{ Test Group (N= 50) } & \multicolumn{4}{|c|}{ Control Group $(\mathrm{N}=50)$} \\
\hline & 1 & 2 & 3 & 4 & 1 & 2 & 3 & 4 \\
\hline Baseline & $27(54 \%)$ & $18(36 \%)$ & $5(10 \%)$ & - & $28(56 \%)$ & $17(34 \%)$ & $5(10 \%)$ & - \\
\hline 1 st Week & $14(28 \%)$ & $12(24 \%)$ & $22(44 \%)$ & $2(4 \%)$ & $26(52 \%)$ & $11(22 \%)$ & $13(26 \%)$ & - \\
\hline 2nd Week & $1(2 \%)$ & $16(32 \%)$ & $22(44 \%)$ & $2(4 \%)$ & $12(24 \%)$ & $19(38 \%)$ & $12(24 \%)$ & $7(14 \%)$ \\
\hline 3rd Week & & $5(10 \%)$ & $19(38 \%)$ & $26(52 \%)$ & $3(6 \%)$ & $12(50 \%)$ & $12(24 \%)$ & $10(20 \%)$ \\
\hline $4^{\text {th }}$ Week & & $2(4 \%)$ & $12(24 \%)$ & $36(72 \%)$ & & $3(26 \%)$ & $23(46 \%)$ & $14(28 \%)$ \\
\hline $5^{\text {th } W e e k}$ & & & $6(12 \%)$ & $44(88 \%)$ & & & $31(62 \%)$ & $19(38 \%)$ \\
\hline $6^{\text {th }}$ Week & & & $3(6 \%)$ & $47(94 \%)$ & & & $26(52 \%)$ & $24(48 \%)$ \\
\hline 7th Week & & & & $50(100 \%$ & & & $5(10 \%)$ & $45(90 \%)$ \\
\hline \multicolumn{9}{|c|}{ Table 2} \\
\hline
\end{tabular}

\begin{tabular}{|c|c|c|c|c|c|c|c|c|}
\hline \multirow[t]{2}{*}{ Study Period } & \multicolumn{4}{|c|}{ Test Group $(n=50)$} & \multicolumn{4}{|c|}{ Control Group $(n=50)$} \\
\hline & $>10$ & $5-10$ & $1-5$ & Nil & $>10$ & $5-10$ & $1-5$ & Nil \\
\hline Baseline & $20(40 \%)$ & $17(34 \%)$ & $13(26 \%)$ & - & $23(46 \%)$ & $15(30 \%)$ & $12(24 \%)$ & - \\
\hline $1^{\text {st } W e e k}$ & $20(40 \%)$ & $17(34 \%)$ & $13(26 \%)$ & - & $25(50 \%)$ & $15(30 \%)$ & $10(20 \%)$ & - \\
\hline $2^{\text {nd }}$ Week & $20(40 \%)$ & $12(24 \%)$ & $16(32 \%)$ & $2(4 \%)$ & $29(58 \%)$ & $10(20 \%)$ & $11(22 \%)$ & - \\
\hline $3^{\text {rd Week }}$ & $16(32 \%)$ & $5(10 \%)$ & $13(26 \%)$ & $16(32 \%)$ & $27(54 \%)$ & $9(18 \%)$ & $10(20 \%)$ & $4(8 \%)$ \\
\hline $4^{\text {th }}$ Week & $16(32 \%)$ & $6(12 \%)$ & $12(24 \%)$ & $16(32 \%)$ & $28(56 \%)$ & $7(14 \%)$ & $11(22 \%)$ & $4(8 \%)$ \\
\hline $5^{\text {th }}$ Week & $10(20 \%)$ & $5(10 \%)$ & $8(16 \%)$ & $2(4 \%)$ & $28(56 \%)$ & $7(14 \%)$ & $9(18 \%)$ & $7(14 \%)$ \\
\hline $6^{\text {th }}$ Week & $4(8 \%)$ & $1(2 \%)$ & $4(8 \%)$ & $41(82 \%)$ & $25(50 \%)$ & $9(18 \%)$ & $4(8 \%)$ & $12(24 \%)$ \\
\hline $7^{\text {th }}$ Week & $2(4 \%)$ & - & - & $48(96 \%)$ & $16(32 \%)$ & $6(12 \%)$ & $6(12 \%)$ & $22(44 \%)$ \\
\hline
\end{tabular}

\section{Table 3}

Inference; Number of patients with No wound surface (Nil) are significantly higher in Test group at 3rd week

\section{Images: Hydrogel Dressings- Test Group}

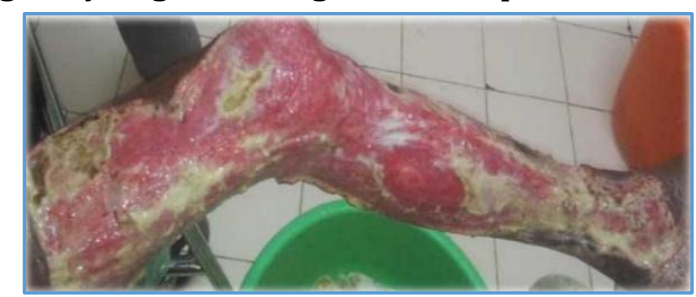

Figure 1. Patient 1. Day 7 Pi Ra-Post debridement Ulcer over Thigh and Leg

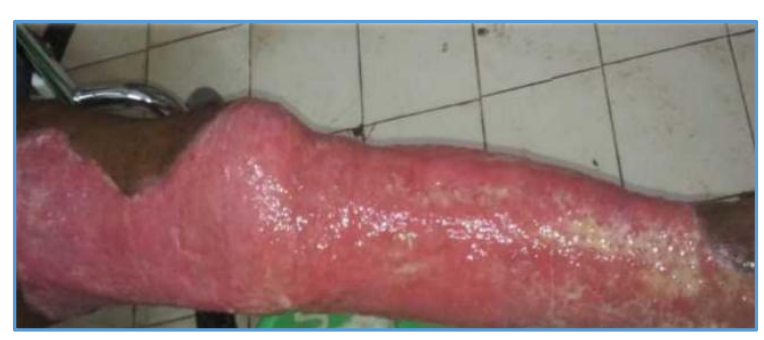

Figure 2. Patient 1. Day 14- Ulcer showing Healthy Granulation Tissue 


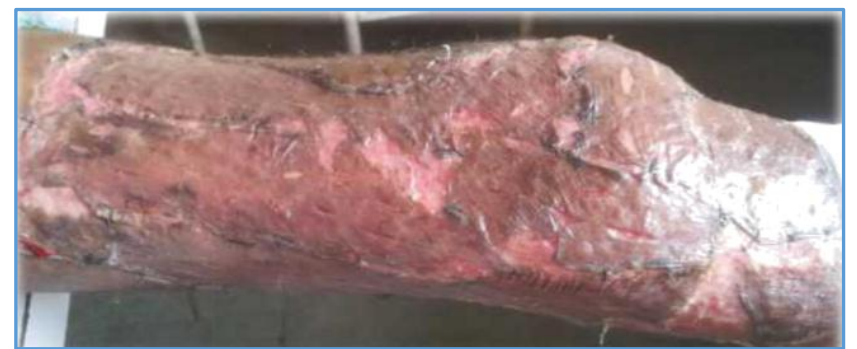

Figure 3. Patient 1. Day 21-Split Skin Grafting Done

\section{Images: Conventional Dressings- Control Group}

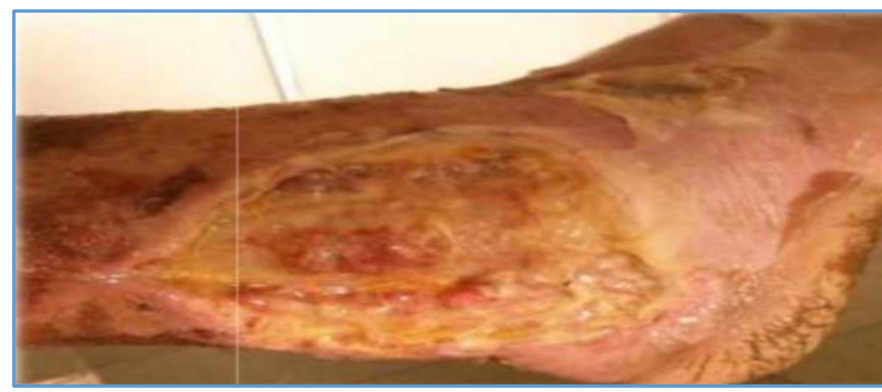

Figure 4. Patient 2. Diabetic Ulcer-Day 1 Ulcer Covered with Slough

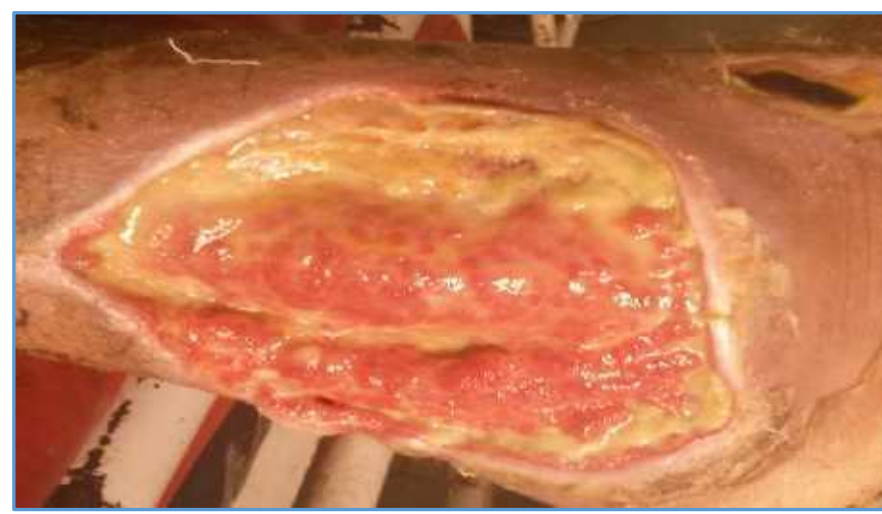

Figure 5. Patient 2. Diabetic Ulcer- Day 14 Ulcer covered with Slough and Minimal Granulation Tissue

\section{DISCUSSION}

In our study, presence of necrotic tissue in 1st week was $76 \%$ in test group after using hydrogel dressing the fall of necrotic tissue was upto $30 \%$ in 4 th week, whereas in control group the presence of necrotic tissue in 1st week was 54\%. After using conventional dressing, the fall of necrotic tissue was upto $34 \%$. So in our study, the use of hydrogel dressing was more superior than the conventional dressing in response to fall in necrotic tissue. Similar study was done by Zoellner P et al,[10] which showed fall in necrotic from $62 \%$ to $23 \%$ by using hydrogel dressing which is similar to our study. The presence of granulation tissue in 1st week was $28 \%$ in test group, after using hydrogel dressing the granulation tissue increased to $52 \%$ in the 3rd week, whereas in control group the presence of granulation tissue in 1 st week was $52 \%$, after using conventional dressing it was only $20 \%$. So in our study, the use of hydrogel dressing was more superior than the conventional dressing in response to presence of granulation tissue. Similar study was done by Zoellner $P$ et al[10] which showed increase in granulation tissue from $25 \%$ to $37 \%$ by using hydrogel dressing, which was almost similar to our study.

In our study the wound surface area epithelialised in test group by using hydrogel dressing was from $68 \%$ to $32 \%$ in the 3rd week, whereas in control group the wound surface area epithelialisation by using conventional dressing was from $92 \%$ to $8 \%$. At the end of 7 th week the wound epithelialisation was $96 \%$ by using hydrogel dressing, whereas $44 \%$ by using conventional dressing. So in our study, the wound surface area epithelialisation was better by using hydrogel dressing than the conventional dressing. Similar study was done by Kaya AZ et al,[11] which showed almost similar results, where $84 \%$ of the wounds epithelialised by hydrogel dressing and $54 \%$ of wounds by conventional dressing.

In our study, the mean hospital stay in test group was $42.9 \pm 3.58$ (SD) days and that in control group was $47.61 \pm$ 1.72 (SD) days. In similar study done by Kaya AZ et al[11] the mean hospital in hydrogel group was 48 days as this study involves only pressure ulcers as the aetiology, whereas our study involves varied aetiologies and the mean age being $53.87 \pm 6.52$, healing was faster. This study demonstrated that enzymatic hydrogel with colloidal silver debridement along with bedside surgical debridement had cumulative effect in reduction of slough, increased granulation tissue and faster wound bed preparation. The test group patients also experienced less pain than the control group, because the need for the bedside surgical debridement is less than the control group.

The test group patients underwent skin grafting, secondary suturing and flap as early as 3rd week than control group, because of faster wound bed preparation. The wound also healed faster. This is due to increased epithelialisation.

\section{CONCLUSION}

By using hydrogel with colloidal silver in combination has proved to be highly effective in reduction of slough, promoting granulation tissue formation and reepithelialisation. Hydrogel with colloidal silver combination proved to be significantly effective in wound bed preparation in comparison with conventional treatment with local antiseptics. It was also seen that the overall hospital stay was comparatively less by using hydrogel dressings. Thus, hydrogel dressing can be considered as a superior option in the management of chronic wounds.

\section{ACKNOWLEDGEMENT}

I would like to thank the Staff of Surgery Department for their support.

\section{REFERENCES}

[1] Becker R, Kröger K. Modern wound care from a socioepidemiological perspective. Wundmanagement 2011;1:15-21.

[2] Purwins S, Herberger K, Debus ES, et al. Cost-of-illness of chronic leg ulcers in Germany. Int Wound J 2010;7(2):97-102.

[3] Pelka R. The economic situation of chronic wounds. Krankenpfl J 1997;35(9):338. 
[4] Palfreyman S, Nelson EA, Michaels JA. Dressings for venous leg ulcers: systematic review and metaanalysis. BMJ 2007;335(7613):244.

[5] Bergin SM, Wraight P. Silver based wound dressing and topical agents for treating diabetic foot ulcers. Cochrane Database Syst Rev 2006;(1): CD005082.

[6] Dumville JC, O'Meara S, Deshpande S, et al. Hydrogel dressing for healing diabetic foot ulcers (review). Cochrane Database Syst Rev 2011;9: CD009101.

[7] Dumville JC, Soares MO, O'Meara S, et al. Systematic review and mixed treatment comparison: dressings to heal diabetic foot ulcers. Diabetologia 2012;55 (7):1902-10.
[8] Singh A, Halder S, Menon GR, et al. Meta-analysis of randomized controlled trials on hydrocolloid occlusive dressing versus conventional gauze dressing in the healing of chronic wounds. Asian J Surg 2004;27(4):326-32.

[9] Bouza C, Munoz A, Amate JM. Efficacy of modern dressings in the treatment of leg ulcers: a systematic review. Wound Repair Regen 2005;13(3):218-29.

[10] Zoellner P, Kapp H, Smola H. Clinical performance of a hydrogel dressing in chronic wounds: a prospective observational study. J Wound Care 2007;16(3):133-6.

[11] Kaya AZ, Turani N, Akyuz M. The effectiveness of a hydrogel dressing compared with standard management of pressure ulcers. J Wound Care 2005;14(1):42-4. 